\title{
Curbing chyle leaks
}

\author{
Ming-Sing Si, MD
}

\author{
From the Department of Cardiac Surgery, Section of Pediatric Cardiovascular Surgery, University of Michigan, \\ Ann Arbor, Mich. \\ Disclosures: Author has nothing to disclose with regard to commercial support. \\ Received for publication May 10, 2016; accepted for publication May 17, 2016; available ahead of print June 14, \\ 2016. \\ Address for reprints: Ming-Sing Si, MD, 11-735 C.S. Mott Children's Hospital SPC 4204, 1540 E Hospital Dr, \\ Ann Arbor, MI 48109-4204 (E-mail: mingsing@umich.edu). \\ J Thorac Cardiovasc Surg 2016;152:e57-8 \\ $0022-5223 / \$ 36.00$ \\ Copyright (C) 2016 by The American Association for Thoracic Surgery \\ http://dx.doi.org/10.1016/j.jtcvs.2016.05.031
}

In this issue of the Journal, a report by Delany and colleagues ${ }^{1}$ describes the use of tissue plasminogen activator (tPA) to reestablish the patency of a clogged pericardial drain in a 16-month-old patient with chronic chylous drainage after cardiac surgery. Their patient underwent a repair of double-outlet right ventricle and had persistent chylous drainage. The chylous pericardial effusion increased in size in the presence of a 19F Blake drain and despite the institution of a low-fat diet. She then underwent a pericardial window procedure with placement of a $15 \mathrm{~F}$ Jackson-Pratt drain (CardinalHealth, Dublin, Ohio) on postoperative day 25 , but the pericardial effusion continued to increase while the drain output decreased. Therefore, tPA was instilled into the drain on postoperative day 30, which subsequently resulted in an increase in drainage with resolution of the pericardial effusion. The pericardial drain was removed 6 days later after tPA instillation.

Although there are several decades of experience in using tPA (or other serine proteases) for clogged pleural tubes and loculated pleural effusions, the instillation of tPA into a clogged pericardial drain for chylous effusion as described by Delany and colleagues is novel. ${ }^{1-4}$ Chyle leaks after cardiac surgery in neonates and infants occur in up to $9 \%$ of cases. ${ }^{5}$ The exact incidence of clogged pericardial tubes secondary to chylous drainage after pediatric cardiac surgery is not known. The observation at our center is that the incidence of clogged pericardial drains secondary is low, occurring mostly in percutaneously placed small-bore pigtail catheters. Nevertheless, the use of tPA to reestablish the patency of clogged drains in the setting of chyle lean is important to eliminate fluid-filled spaces and promote apposition of mediastinal tissue planes important for healing (or scarring) that presumably leads to the cessation of the chyle leak.

This case also highlights the variability in approach to managing chyle leaks after pediatric cardiac surgery. At our center, we follow a clinical practice guideline that involves a medium-chain triglyceride (and low long-chain fatty acid) diet for low-volume chylothorax $(<20 \mathrm{~mL} / \mathrm{kg} /$ d) and a regimen of non per os (NPO), total parenteral nutrition, and possible thoracic duct ligation for high-volume

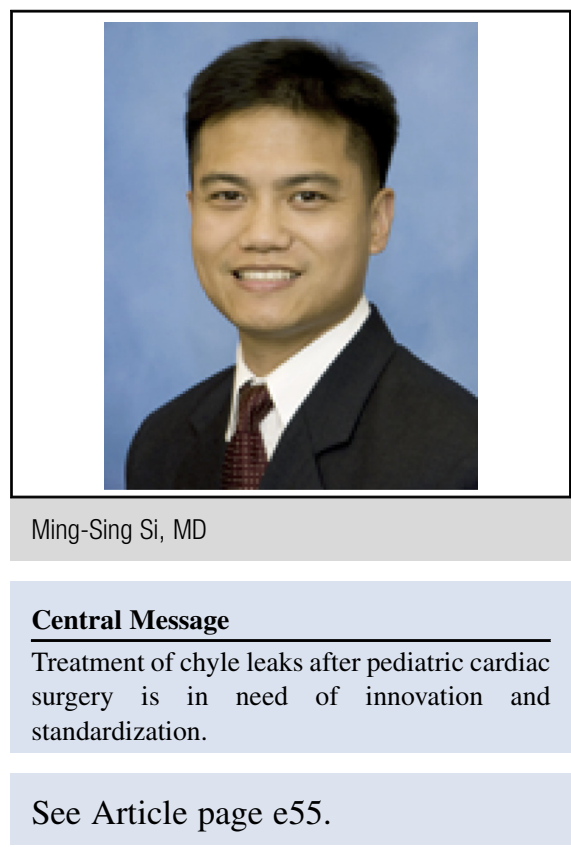

chylothorax. ${ }^{6}$ Perhaps a trial of NPO would have benefitted this patient with persistent and enlarging pericardial effusion; one can speculate that a regimen of NPO in patients eliminates the chylous component of the drainage, decreases viscosity, and decreases the probability of drain clogging. Treating persistent, high-volume chyle leak with thoracic duct ligation also is effective, but the longterm effects of this procedure are unknown. Recently, we have undertaken an even more targeted approach to these patients by selective embolization of chyle performed by our interventional radiologists, thereby avoiding prolonged periods of NPO. The rate and durability of success of this approach remain to be seen. Yet another approach that one can postulate is the prophylactic application of fibrin glue laden with lymphangiogenesis-promoting agents (eg, recombinant vascular endothelial growth factor-C or sphingosine-1-phosphate ${ }^{7,8}$ ) to areas of surgical dissection to aid in lymphatic repair and regeneration in patients at high risk of developing chyle leak after pediatric cardiac surgery.

Postoperative chyle leak is a well-recognized complication of pediatric cardiac surgery and carries significant morbidity and public health cost. ${ }^{9}$ The novel description supplied by Delany and colleagues ${ }^{1}$ will assist in addressing one particular piece of the postoperative chyle leak problem. However, to make even a further impact in these affected patients, significantly more effort is needed from our field to formulate innovative and effective strategies for curbing chyle leaks. 


\section{References}

1. Delany DR, Newman JW, Atz AM. Tissue plasminogen activator for mediastinal tube clearance in pediatric chylous effusion: a case report. J Thorac Cardiovasc Surg. 2016;152:e55-6.

2. Sahn SA. Use of fibrinolytic agents in the management of complicated parapneumonic effusions and empyemas. Thorax. 1998;53:S65.

3. Kuan YC, How SH, Ng TH, Rani MFA. Intrapleural streptokinase for the treatment of chylothorax. Respir Care. 2011;56:1953-5.

4. Ekingen G, Guvenc BH, Sozubir S, Tuzlaci A, Senel U. Fibrinolytic treatment of complicated pediatric thoracic empyemas with intrapleural streptokinase. Eur J Cardiothorac Surg. 2004;26:503-7.

5. Biewer ES, Zurn C, Arnold R, Glockler M, Schulte-Monting J, Schlensak C, et al. Chylothorax after surgery on congenital heart disease in newborns and infants-risk factors and efficacy of MCT-diet. $J$ Cardiothorac Surg. 2010;5:127.

6. Yeh J, Brown ER, Kellogg KA, Donohue JE, Yu S, Gaies MG, et al. Utility of a clinical practice guideline in treatment of chylothorax in the postoperative congenital heart patient. Ann Thorac Surg. 2013;96:930-6.

7. Aspelund A, Robciuc MR, Karaman S, Makinen T, Alitalo K. Lymphatic system in cardiovascular medicine. Circ Res. 2016;118:515-30.

8. Yoon CM, Hong BS, Moon HG, Lim S, Suh PG, Kim YK, et al. Sphingosine-1phosphate promotes lymphangiogenesis by stimulating S1P1/Gi/PLC/Ca2+ signaling pathways. Blood. 2008;112:1129-38.

9. Mery CM, Moffett BS, Khan MS, Zhang W, Guzman-Pruneda FA, Fraser CD, et al. Incidence and treatment of chylothorax after cardiac surgery in children: analysis of a large multi-institution database. J Thorac Cardiovasc Surg. 2014;147:678-86.e1. 